\title{
PROTECTIVE EFFECT OF SYNTHETIC ANTIOXIDANTS AND ETHANOLIC EXTRACT OF BACOPA MONNIERI AGAINST LEAD TOXICITY INDUCED METABOLIC DYSFUNCTIONS IN MICE BRAIN AND LIVER HOMOGENATES: AN IN VITRO APPROACH
}

\author{
FLORA C SHAH*, NAYAN K JAIN \\ Department of Life-Science, University School of Sciences, Gujarat University, Ahmedabad - 380009, Gujarat, India. \\ Email: drflorashah88@gmail.com
}

Received: 04 January 2019, Revised and Accepted: 13 March 2019

\begin{abstract}
Objective: The main objective of the present study was to investigate the ameliorative potential of synthetic antioxidants mixture comprising $\mathrm{N}$-acetyl cysteine, ascorbic acid, tocopheryl acetate, and thiamine as micronutrient combinational therapy and ethanolic extract of Bacopa monnieri as herbal antioxidant therapy approach against lead toxicity-induced metabolic dysfunctions in vitro.

Methods: Experimental study involved in vitro exposure of mice brain and liver homogenates to different doses (100 $\mu \mathrm{M}, 250 \mu \mathrm{M}$, and $500 \mu \mathrm{M})$ of lead acetate. The study also involved coadministration of high-dose lead acetate $(500 \mu \mathrm{M})$ and specific dosage of synthetic antioxidants or ethanolic extract of B. monnieri separately to homogenate cultures. Alterations in metabolic parameters of protein levels and lipid peroxidation were analyzed for evaluating the protective effect of synthetic antioxidants and B. monnieri against lead intoxication.

Results: Results revealed dose-dependent statistically significant $(\mathrm{p}<0.001)$ reduction in protein levels and elevation in lipid peroxidation in lead acetate exposed mice brain and liver homogenates as compared to their respective control groups. Coadministration of lead acetate and synthetic antioxidants mixture or B. monnieri in the brain and liver homogenates conferred protection and manifested maintenance of studied biochemical parameters nearest to control groups. Ameliorative efficacy of $B$. monnieri against lead-induced neurotoxicity and hepatotoxicity was found to be more pronounced than that of a mixture of synthetic antioxidants.
\end{abstract}

Conclusion: Synthetic antioxidants mixture (N-acetyl cysteine, ascorbic acid, tocopheryl acetate, and thiamine) and B. monnieri exhibited remarkable therapeutic efficacy against lead toxicity-induced metabolic dysfunctions in mice brain and liver homogenates by virtue of their antioxidant, neuroprotective, and hepatoprotective abilities.

Keywords: Lead toxicity, Neurotoxicity, Hepatotoxicity, Synthetic antioxidants, Bacopa monnieri, Neuroprotective activity, Hepatoprotective activity, Amelioration, Metabolism.

(C) 2019 The Authors. Published by Innovare Academic Sciences Pvt Ltd. This is an open access article under the CC BY license (http://creativecommons. org/licenses/by/4. 0/) DOI: http://dx.doi.org/10.22159/ajpcr.2019.v12i4.31851

\section{INTRODUCTION}

Lead metal is considered as one of the most pervasive and dreaded occupational and environmental toxicants of global concern. On the criteria of the occurrence frequency of toxicological consequences and human exposure potential, Agency for Toxic Substances and Disease Registry has placed lead metal at the second position in the priority list of "top 20 hazardous substances" [1].

Lead compounds are employed indiscriminately in the industries for manufacturing of lead-acid batteries, cosmetics, paints, weights, toys, kitchen utensils, ayurvedic medicines, lead pipes, ammunitions, and radiation shields due to their cost-effectiveness and easy availability [2]. Non-biodegradable nature of lead facilitates its entry into the food chain resulting in its bio-magnification. Lead accumulation in experimental animal and human tissues has been found to be associated with considerable health risks due to its tendency to induce a broad range of physiological and biochemical dysfunctions $[3,4]$. Lead has been well documented as a cumulative metabolic poison at higher concentrations [5]. Lead exposure has the propensity to induce alterations in mammalian metabolism due to its potent systemic toxicity. Lead exposure has been associated with triggering of detrimental effects on the nervous system [6-8], hemopoietic system [9], hepatic system $[10,11]$, and reproductive system [12].

Clinical manifestation of lead toxicity can be observed in multiple organs. The most deceptive form of lead toxicity is that affecting the nervous system as brain is the prime accumulator of inorganic lead. Lead has been reported as a potent neurotoxin, and it particularly affects the developing nervous system [7]. Exposure to even low levels of lead is associated with behavioral abnormalities, hearing impairment, learning disabilities, and cognitive dysfunctions in experimental animals as well as human beings $[13,14]$. Liver is the most frequent target organ for this metallic toxicant. It has been reported as the largest repository of lead (33\%) per $\mathrm{g}$ of wet tissue among the soft tissues followed by kidney cortex and medulla in humans [15]. Lead-induced hepatotoxicity is of major concern because liver plays a key role in carbohydrate metabolism, protein metabolism, lipid metabolism, energy production, and detoxification of xenobiotics [16]. Lead exposure has been reported to cause infiltration of lymphocytes, liver cirrhosis, and disruption of liver structure as well as functions $[17,18]$. Hence, lead-induced neurotoxicity and hepatotoxicity mediated alterations in metabolic functions can be considered as one of the major issues of public health concern.

Keeping this perspective in view, present in vitro study was intended with the objective to elucidate the underlying deleterious mechanism of oxidative stress resulted due to lead intoxication through exploration of metabolic alterations in protein levels and lipid peroxidation in mice brain as well as liver homogenate cultures. To overcome lead-induced oxidative stress resulted due to pro-oxidant/antioxidant imbalance within mammalian tissues; a therapeutic strategy of exogenous supplementation of antioxidants can be beneficial. Antioxidants can also act as strong metal chelating agents and mobilize metals from hard 
and soft tissues. These multifaceted benefits of antioxidants make them strong ameliorative agents to be utilized clinically as antidotes for the treatment of lead poisoning. Considering this facet, another objective of the present in vitro study was to explore ameliorative efficacy of synthetic antioxidants such as $\mathrm{N}$-acetyl cysteine, ascorbic acid, tocopheryl acetate, and thiamine in a novel mixture to exert synergistic effect against lead-induced neurotoxic and hepatotoxic metabolic dysfunctions as combinational therapy approach which had not been worked out earlier. In addition, there is a paucity of knowledge regarding herbal antioxidants with maximum cost-effectiveness and minimum side effects that can act as ameliorative agents against lead toxicity. Bacopa monnieri (Brahmi) is a traditional ayurvedic plant belonging to the Scrophulariaceae family with a wide spectrum of pharmacological properties. Keeping this perspective, the other major objective of present study was to investigate the possible ameliorative potential of medicinal plant B. monnieri as a novel neuroprotective and hepatoprotective agent against lead toxicityinduced metabolic dysfunctions in mammalian tissues.

\section{METHODS}

\section{Chemicals}

All the chemicals utilized in the present research work were analytical grade reagents (AR). Lead acetate trihydrate, N-Acetyl cysteine (NAC), ascorbic acid (Vitamin-C), tocopheryl acetate (Vitamin-E), thiamine (Vitamin- $\mathrm{B}_{1}$ ), and other chemicals having $99 \%$ purity used in the present study were purchased from HiMedia, Sigma and Merck Laboratory Pvt., Ltd., India.

\section{Preparation of lead acetate and antioxidants reagents}

About $10 \mathrm{mM}$ stock solution of lead acetate was prepared in doubled distilled water. A definite volume of this stock solution was utilized in a final volume of the reaction mixture, so as to get the required concentrations of $100 \mu \mathrm{M}, 250 \mu \mathrm{M}$, and $500 \mu \mathrm{M}$ lead acetate dosage. N-Acetyl cysteine, ascorbic acid, thiamin, B. monnieri extract, and other reagents employed for in vitro assays in the present study were dissolved in double distilled water. Tocopheryl acetate was administered directly in the form of Evionemulsion syrup after purchasing from Merck Laboratory.

\section{Preparation of the ethanolic extract of $B$. monnieri}

Creeper plant B. monnieri was collected from Botanical Garden of University School of Sciences, Gujarat University, Ahmedabad, India, during December. The plant was identified and authenticated by Botany Department of the University with a voucher specimen submitted to the herbarium. The whole plant of B. monnieri was thoroughly washed with double distilled water and cut into small pieces. Plant material was dried in the shade in dust free condition for the period of 1 week at room temperature and finally ground to coarse powder. $10 \mathrm{~g}$ of powdered whole plant material was mixed with $100 \mathrm{ml}$ of $90 \%$ ethanol as solvent and subjected to Soxhlet extraction at $78^{\circ} \mathrm{C}$ for 11 -hrs. The resultant crude extract was concentrated, air-dried and stored at $20^{\circ} \mathrm{C}$ in a dark bottle for further use.

\section{Experimental animals}

Fresh mice brain and liver tissues were utilized as mammalian vital organs for the preparation of homogenate cultures in the present in vitro study. The main purpose of in vitro experimental design was the minimization of animal usage. Healthy male Swiss albino mice (Mus musculus) of 4-5 weeks of age and weighing about 30-35 g were obtained from Cadila Pharmaceuticals, Dholka, India, under Animal Maintenance and Registration No. 167/1999/CPCSEA obtained from the Ministry of Social Justice and Empowerment, Government of India. Animals were caged separately in the animal house of Gujarat University as per guidelines of Committee for the Purpose of Control and Supervision of Experiments on Animals (CPCSEA). Animals were maintained under well-regulated lightdark (12 h:12 h) schedule at $26 \pm 2^{\circ} \mathrm{C}$ and fed with standard commercial laboratory chow along with tap water ad libitum.

\section{Sample collection}

After the acclimatization period of 1 week, the animals were fasted overnight and sacrificed on the next day by subjecting them to high ether anesthesia. Cranium and abdominal cavity of mice were opened carefully, and brain as well as liver samples were dissected out. Tissues were washed in cold normal saline, blotted dry, and subjected to the process of homogenization.

\section{Preparation of tissue homogenates}

Nearly $2 \%$ tissue homogenates of each of fresh brain and liver were prepared separately in chilled double distilled water for estimation of protein contents while $10 \%$ tissue homogenates were prepared in ice cold $0.1 \mathrm{M}$ phosphate buffer $(\mathrm{pH}=7.4)$ for estimation of lipid peroxidation.

\section{Experimental design}

The in vitro study experiment was divided into two separate phases. During the first phase, different doses of lead acetate were administered in mice brain and liver homogenate cultures to investigate the leadinduced metabolic alterations in biochemical parameters. The second phase involved coadministration of specific dosage of lead acetate and synthetic antioxidants mixture as well as lead acetate and herbal antioxidant $B$. monnieri extract in homogenate cultures as per the experimental groups to investigate their ameliorative effect against lead toxicity. The dosage selection for lead acetate, synthetic antioxidants, and B. monnieri extract was based on standardization carried out in the laboratory using serial dilution technique to get effective concentrations for in vitro analysis and derived on the basis of extrapolation of available data from literature through calculation of organ weight ratio for mammalian tissues.

\section{Experimental protocol}

The mice brain and liver homogenates $(1 \mathrm{ml})$ were divided into different experimental groups and exposed to different dosage of lead acetate, synthetic antioxidants mixture as well as ethanolic extract of $B$. monnieri separately for duration of 1 -h in experimental tubes at $37^{\circ} \mathrm{C}$ in BOD incubator containing $5 \% \mathrm{CO}_{2}$ for estimation of biochemical parameters.

\section{Experimental groups}

Experimental design comprised eight experimental groups:

1. Group-I: UC

$$
\text { Untreated control group }
$$

2. Group-II: A-I

Synthetic antioxidants mixture exposed group

(Brain culture: NAC-8 $\mu \mathrm{g} / \mathrm{ml}+$ ascorbic acid-1.78 mg/ml + tocopheryl acetate $-1.42 \mathrm{mg} / \mathrm{ml}+$ thiamine $-0.3 \mathrm{mg} / \mathrm{ml}$ )

(Liver culture: NAC-1.8 $\mu \mathrm{g} / \mathrm{ml}+$ ascorbic acid- $0.381 \mathrm{mg} / \mathrm{ml}+$ tocopheryl acetate $-0.305 \mathrm{mg} / \mathrm{ml}+$ thiamine $-57.1 \mu \mathrm{g} / \mathrm{ml}$ )

3. Group-III: A-II

Herbal antioxidant exposed group

(B. monnieri extract- Brain culture: $0.1 \mathrm{mg} / \mathrm{ml}$; Liver culture: $0.1 \mathrm{mg} / \mathrm{ml}$ )

4. Group-IV: Low dose (LD)

Lead acetate LD $(100 \mu \mathrm{M})$ exposed group

5. Group-V: Mid dose (MD)

Lead acetate MD (250 $\mu \mathrm{M})$ exposed group

6. Group-VI: High dose (HD)

Lead acetate HD $(500 \mu \mathrm{M})$ exposed group

7. Group-VII: HD + A-I

Lead acetate $(500 \mu \mathrm{M})$ and synthetic antioxidants mixture (coadministration) exposed group and

8. Group-VIII: HD + A-II

Lead acetate $(500 \mu \mathrm{M})$ and herbal antioxidant (B. monnieri extract) (coadministration) exposed group.

\section{Biochemical analysis}

\section{Protein estimation assay}

To evaluate the impact of lead acetate as well as synthetic and herbal antioxidants exposure on protein metabolism, level of soluble protein was determined in brain and liver homogenates by the standard method of Lowry et al. (1951) using alkaline copper solution and 
Folin-Ciocalteu reagent [19]. The intensity of blue color developed was measured at $600 \mathrm{~nm}$ spectrophotometrically (Systronics ultraviolet [UV]-visible spectrophotometer 167). Protein levels were expressed as mg protein/100 mg fresh tissue weight.

\section{Lipid peroxidation assay}

For investigation of oxidative stress-inducing capacity of lead and antioxidative potential of synthetic and herbal antioxidants, lipid peroxidation was induced by the addition of $\mathrm{H}_{2} \mathrm{O}_{2}$ in the leadexposed tissue homogenates. The reaction mixtures containing tissue homogenates, sodium dodecyl sulfate, glacial acetic acid, and thiobarbituric acid were then heated at $80^{\circ} \mathrm{C}$ for 1-h in boiling water bath. After completion of the reaction, the samples were centrifuged at $1500 \mathrm{rpm}$ for $15 \mathrm{~min}$, and the optical density of the pink chromogen was recorded at $535 \mathrm{~nm}$ spectrophotometrically (Systronics UVvisible spectrophotometer 167). Lipid peroxidation was determined by measurement of thiobarbituric acid reactive substances (TBARS) according to the standard method of Ohkawa et al. (1979) [20]. Lipid peroxidation was expressed in terms of nanomoles of malondialdehyde (MDA) produced/60 min/100 mg tissue weight.

\section{Statistical analysis}

The results data of in vitro study were expressed as mean \pm standard error of the mean (SEM) for each parameter $(n=5)$. Statistical analysis was performed using GraphPad Prism software, version 5.03. Comparison among different groups was made by one-way analysis of variance followed by Tukey's post hoc test. The level of significance was accepted with $\mathrm{p}<0.05$

\section{RESULTS}

Effect of lead and antioxidants on the protein content of mice brain homogenates

Effect of lead acetate exposure on protein metabolism and its amelioration using synthetic and herbal antioxidants was evaluated in the in vitro condition in brain homogenate cultures. Exposure of brain homogenates to different concentrations $(100 \mu \mathrm{M}, 250 \mu \mathrm{M}$, and $500 \mu \mathrm{M}$ ) of lead acetate showed a significant reduction in protein levels as compared to control group in a dose-dependent manner $\left(\mathrm{R}^{2}=0.999\right)$ (Table 1). Results revealed that protein content statistically significantly $(p<0.001)$ decreased as the concentration of lead acetate was increased as compared to control group (LD: $16.06 \%$, MD: 34.28\%, HD: 45.39\%) (Table 2). Maximum decline (45.39\%) in protein content was observed at $500 \mu \mathrm{M}$ lead acetate exposure as compared to control. Results also emphasized that administration of mixture of synthetic antioxidants as well as ethanolic extract of B. monnieri separately (Groups VII and VIII) along with the highest concentration $(500 \mu \mathrm{M})$ of lead in brain homogenate cultures statistically very significantly exerted protective effect against lead toxicity $(\mathrm{p}<0.001)$ through prevention of reduction in protein levels by showing the decline up to only $2.15 \%$ and $1.21 \%$, respectively, as compared to control group and increase in protein levels by $79.19 \%$ and $80.89 \%$, respectively, as compared to the high dose of lead acetate exposed group (Table 2).

\section{Effect of lead and antioxidants on lipid peroxidation level of mice brain homogenates}

For analyzing oxidative stress induced by lead acetate exposure and antioxidative as well as the neuroprotective potential of selected synthetic and herbal antioxidants, the amount of metabolic products of lipid peroxidation in the form of malondialdehyde as TBARS was measured in brain homogenate cultures. Exposure of mice brain homogenates to three different concentrations $(100 \mu \mathrm{M}, 250 \mu \mathrm{M}$, and $500 \mu \mathrm{M})$ of lead acetate showed statistically significant $(\mathrm{p}<0.001)$ dosedependent $\left(R^{2}=0.998\right)$ increase in MDA levels (Table 1$)$ as compared to control group (LD: 32.05\%, MD: 84.10\%, and HD: 149.52\%) (Table 2). Maximum elevation in lipid peroxidation (149.52\%) was obtained at $500 \mu \mathrm{M}$ concentration of lead acetate exposure. Administration of the mixture of synthetic antioxidants as well as $B$. monnieri ethanolic extract separately (Groups VII and VIII) along with highest lead concentration $(500 \mu \mathrm{M})$ in brain homogenate cultures statistically very significantly

Table 1: In vitro effect of lead and antioxidants on protein metabolism and oxidative stress indices of control and exposed mice brain homogenates

\begin{tabular}{|c|c|c|c|}
\hline \multirow[t]{2}{*}{ Group no } & \multirow[t]{2}{*}{ Experimental groups } & \multicolumn{2}{|c|}{ Experimental parameters } \\
\hline & & $\begin{array}{l}\text { Protein levels mg/100 mg } \\
\text { tissue wt. }\end{array}$ & $\begin{array}{l}\text { Lipid peroxidation nano moles } \\
\text { MDA } / \mathrm{h} / \mathrm{mg} \text { protein }\end{array}$ \\
\hline Group-I & Untreated control & $3.959 \pm 0.006$ & $796.087 \pm 4.006$ \\
\hline \multicolumn{4}{|c|}{ Antidotes exposed groups } \\
\hline Group-II & Synthetic antioxidants mixture (A-I) & $3.964 \pm 0.004$ & $782.601 \pm 2.457$ \\
\hline Group-III & Bacopa monnieri extract (A-II) & $3.975 \pm 0.005$ & $774.047 \pm 2.120$ \\
\hline \multicolumn{4}{|c|}{ Toxin exposed groups } \\
\hline Group-IV & Lead acetate low dose $(100 \mu \mathrm{M})$ & $3.323 \pm 0.007^{\mathrm{a} *}$ & $1051.243 \pm 5.487^{\mathrm{a} *}$ \\
\hline Group-V & Lead acetate mid dose $(250 \mu \mathrm{M})$ & $2.602 \pm 0.004^{\mathrm{a} *}$ & $1465.632 \pm 4.456^{\mathrm{a} *}$ \\
\hline Group-VI & Lead acetate high dose $(500 \mu \mathrm{M})$ & $2.162 \pm 0.005^{\mathrm{a} *}$ & $1986.407 \pm 13.41^{\text {a* }}$ \\
\hline \multicolumn{4}{|c|}{ Toxin+Antidotes exposed groups } \\
\hline Group-VII & Lead acetate high dose $(500 \mu \mathrm{M})(\mathrm{HD})+(\mathrm{A}-\mathrm{I})$ & $3.874 \pm 0.007^{\mathrm{b} *}$ & $835.470 \pm 7.674^{\mathrm{b} *}$ \\
\hline Group-VIII & Lead acetate high dose $(500 \mu \mathrm{M})(\mathrm{HD})+(\mathrm{A}-\mathrm{II})$ & $3.911 \pm 0.002^{\mathrm{b} *}$ & $811.229 \pm 3.837^{\mathrm{b} *}$ \\
\hline
\end{tabular}

([A-I] = NAC - $8 \mu \mathrm{g} / \mathrm{ml}+$ Ascorbic acid $-1.78 \mathrm{mg} / \mathrm{ml}+$ Tocopheryl acetate $-1.42 \mathrm{mg} / \mathrm{ml}+$ Thiamine $-0.3 \mathrm{mg} / \mathrm{ml})([\mathrm{A}-\mathrm{II}]=$ Bacopa monnieri - 0.1 mg/ml). *p<0.001. Values

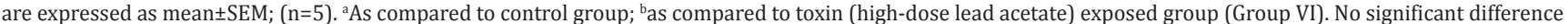
was noted between untreated control and antidotes control groups. SEM: Standard error of mean

Table 2: Gross effect of lead acetate and antioxidants on mice brain homogenate cultures in vitro (percentage of difference with respect to their control and high-dose lead-exposed groups)

\begin{tabular}{|c|c|c|c|c|c|c|c|c|}
\hline S. No. & Biochemical parameters & $\begin{array}{l}\text { Group IV } \\
\text { (LD) }\end{array}$ & $\begin{array}{l}\text { Group Va } \\
\text { (MD) }\end{array}$ & $\begin{array}{l}\text { Group VI } \\
\text { (HD) }\end{array}$ & $\begin{array}{l}\text { Group VII } \\
(H D+A-I)\end{array}$ & $\begin{array}{l}\text { Group VIII }^{\mathrm{a}} \\
(\mathrm{HD}+\mathrm{A} \text {-II) }\end{array}$ & $\begin{array}{l}\text { Group VII } \\
(\text { HD + A-I) }\end{array}$ & $\begin{array}{l}\text { Group VIII }^{b} \\
(\mathrm{HD}+\mathrm{A}-\mathrm{II})\end{array}$ \\
\hline 1. & Protein levels & 16.06 & 34.28 & 45.39 & 2.15 & 1.21 & $79.19^{*}$ & $80.89 *$ \\
\hline 2. & Lipid peroxidation & $32.05^{*}$ & $84.10^{*}$ & $149.52^{*}$ & $4.95^{*}$ & $1.90^{*}$ & 57.94 & 59.16 \\
\hline
\end{tabular}

All values are expressed in percentage of decrease or $*$ increase. ${ }^{a}$ As compared to control group. ${ }^{\mathrm{b}}$ As compared to toxin (high-dose lead acetate) exposed Group-VI. LD $=100 \mu \mathrm{M}$ lead acetate; $\mathrm{MD}=250 \mu \mathrm{M}$ lead acetate; $\mathrm{HD}=500 \mu \mathrm{M}$ lead acetate; $(\mathrm{A}-\mathrm{I})=(\mathrm{NAC}-8 \mu \mathrm{g} / \mathrm{ml}+$ ascorbic acid-1.78 mg $/ \mathrm{ml}+$ tocopheryl acetate $-1.42 \mathrm{mg} / \mathrm{ml}+$ thiamine- $0.3 \mathrm{mg} / \mathrm{ml}$ ). (A-II) =Bacopa monnieri extract $-0.1 \mathrm{mg} / \mathrm{ml}$ 
$(\mathrm{p}<0.001)$ prevented the increase in MDA level up to $4.95 \%$ and $1.90 \%$ as compared to control group as well as reduced the levels of MDA by $57.94 \%$ and $59.16 \%$, respectively, as compared to high-dose leadexposed group and exerted amelioration in oxidative stress induced by lipid peroxidation (Table 2).

Effect of lead and antioxidants on the protein content of mice liver homogenates

In vitro exposure of liver homogenate cultures to different concentrations $(100 \mu \mathrm{M}, 250 \mu \mathrm{M}$, and $500 \mu \mathrm{M})$ of lead acetate showed a significant reduction in protein levels as compared to control group (Table 3). Results revealed that protein content statistically significantly $(p<0.001)$ decreased in a dose-dependent manner $\left(R^{2}=0.999\right)$ as the concentration of lead was increased with respect to control group (LD: 12.40\%, MD: 18.18\%, and HD: 59.67\%) (Table 4). Maximum decline in protein content was observed at $500 \mu \mathrm{M}$ lead exposure $(59.67 \%)$ as compared to the control group. Results also revealed that administration of mixture of synthetic antioxidants or ethanolic extract of $B$. monnieri to Group VII and Group VIII respectively along with the highest concentration $(500 \mu \mathrm{M})$ of lead in liver homogenate cultures imparted statistically very significant $(p<0.001)$ protection against lead toxicity through prevention of reduction in protein levels as revealed by decline up to $11.41 \%$ and $10.23 \%$ respectively as compared to control group and increase in protein levels by $119.70 \%$ and $122.63 \%$ respectively as compared to high dose lead acetate exposed group (Table 4)

Effect of lead and antioxidants on lipid peroxidation level of mice liver homogenates

For determination of oxidative stress-inducing capacity of lead acetate and antioxidative as well as the hepatoprotective potential of selected synthetic and herbal antioxidants, the amount of metabolic products of lipid peroxidation in the form of MDAs was measured in liver homogenate cultures. Exposure of mice liver homogenate cultures to three different concentrations $(100 \mu \mathrm{M}, 250 \mu \mathrm{M}$, and $500 \mu \mathrm{M})$ of lead acetate in in vitro condition showed statistically significant $(\mathrm{p}<0.001)$ increase in MDA levels in a dose-dependent manner $\left(\mathrm{R}^{2}=0.997\right)$
(Table 3) as compared to control group (LD: 48.31\%, MD: 69.07\%, and HD: $278.50 \%$ ) (Table 4). Maximum lipid peroxidation (278.50\%) was obtained at the $500 \mu \mathrm{M}$ concentration of lead acetate exposure. Administration of the mixture of synthetic antioxidants as well as B. monnieri ethanolic extract separately (Groups VII and VIII) along with highest lead concentration $(500 \mu \mathrm{M})$ in liver homogenate cultures statistically very significantly $(\mathrm{p}<0.001)$ reduced the levels of MDA by $18.71 \%$ and $14.85 \%$ as compared to control group as well as $68.64 \%$ and $69.66 \%$, respectively, as compared to high-dose lead-exposed group and exhibited amelioration against oxidative stress induced by lipid peroxidation (Table 4).

\section{DISCUSSION}

The present experimental study revealed that lead acetate exposure in vitro caused statistically extremely significant decrease in protein content of mice brain and liver homogenate cultures as compared to their respective controls. The principal reason for the reduction in protein content might be the interference of lead with -SH groups of enzyme systems essential to cellular metabolism [21,22]. Further MDA formed as by-products of lipid peroxidation might react with $-\mathrm{SH}$ groups of proteins and inhibit enzymes requiring -SH groups for their activities [23]. Lipid peroxidation products such as hydroperoxides can inhibit protein synthesis and alter chemotactic activity [24]. Lead has been reported to form mercaptides with thiol groups of cysteine and less stable complexes with other amino acid side chains [25]. In the present study, reduction obtained in protein levels aftermath lead exposure could be attributed to their damage by singlet oxygen, often due to oxidation of essential amino acids, especially, methionine, tryptophan, histidine, or cysteine residues. The alteration in protein content could be the outcome of lead-induced inhibition of protein biosynthesis, which might be the result increased level of proteolysis [26]. Lead has been reported to perturb protein biosynthesis in hepatocytes, including the structural proteins [27]. Lead toxicity has been reported to cause hemolysis and deamination of proteins [28]. $\mathrm{Pb}^{2+}$ perturbs intracellular $\mathrm{Ca}^{2+}$ homeostasis [29] leading to endoplasmic reticulum

Table 3: In vitro effect of lead and antioxidants on protein metabolism and oxidative stress indices of control and exposed mice liver homogenates

\begin{tabular}{|c|c|c|c|}
\hline \multirow[t]{2}{*}{ Group no. } & \multirow[t]{2}{*}{ Experimental groups } & \multicolumn{2}{|l|}{ Experimental parameters } \\
\hline & & Protein levels mg/100 mg tissue wt. & $\begin{array}{l}\text { Lipid peroxidation nano moles } \\
\text { MDA/h/mg protein }\end{array}$ \\
\hline Group-I & Untreated control & $5.337 \pm 0.003$ & $582.516 \pm 2.148$ \\
\hline \multicolumn{4}{|c|}{ Antidotes exposed groups } \\
\hline Group-II & Synthetic antioxidants mixture (A-I) & $5.332 \pm 0.005$ & $601.106 \pm 5.266$ \\
\hline Group-III & Bacopa monnieri extract (A-II) & $5.342 \pm 0.003$ & $593.932 \pm 2.710$ \\
\hline \multicolumn{4}{|c|}{ Toxin exposed groups } \\
\hline Group-IV & Lead acetate low dose (LD) $(100 \mu \mathrm{M})$ & $4.675 \pm 0.006^{\mathrm{a} *}$ & $863.907 \pm 2.932^{\mathrm{a} *}$ \\
\hline Group-V & Lead acetate mid dose (MD) $(250 \mu \mathrm{M})$ & $4.367 \pm 0.005^{a *}$ & $984.853 \pm 5.654^{\mathrm{a} *}$ \\
\hline Group-VI & Lead acetate high dose (HD) $(500 \mu \mathrm{M})$ & $2.152 \pm 0.005^{\mathrm{a} *}$ & $2204.855 \pm 25.69^{\mathrm{a} *}$ \\
\hline \multicolumn{4}{|c|}{ Toxin antidotes exposed groups } \\
\hline Group-VII & Lead acetate high dose $(500 \mu \mathrm{M})(\mathrm{HD})+(\mathrm{A}-\mathrm{I})$ & $4.728 \pm 0.004^{\mathrm{b} *}$ & $691.516 \pm 7.197^{\mathrm{b} *}$ \\
\hline Group-VIII & Lead acetate high dose $(500 \mu \mathrm{M})(\mathrm{HD})+(\mathrm{A}-\mathrm{II})$ & $4.791 \pm 0.004^{\mathrm{b} *}$ & $668.998 \pm 5.921^{\mathrm{b} *}$ \\
\hline
\end{tabular}

([A-I] = NAC-1.8 $\mu \mathrm{g} / \mathrm{ml}+$ ascorbic acid-0.381 mg/ml+tocopheryl acetate $-0.305 \mathrm{mg} / \mathrm{ml}+$ thiamine $-57.1 \mu \mathrm{g} / \mathrm{ml}$ ) ([A-II] = Bacopa monnieri $-0.1 \mathrm{mg} / \mathrm{ml}]$

${ }^{*} \mathrm{p}<0.001$. Values are expressed as mean $\pm \mathrm{SEM} ;(\mathrm{n}=5)$. ${ }^{a} \mathrm{As}$ compared to control group; bas compared to toxin (high-dose lead acetate) exposed group (Group VI). No significant difference was noted between untreated control and antidotes control groups. MDA: Malondialdehyde, SEM: Standard error of mean

Table 4: Gross effect of lead acetate and antioxidants on mice liver homogenate cultures in vitro (percentage of difference with respect to their control and high-dose lead-exposed groups)

\begin{tabular}{|c|c|c|c|c|c|c|c|c|}
\hline S. No. & Biochemical parameters & $\begin{array}{l}\text { Group IV } \\
\text { (LD) }\end{array}$ & $\begin{array}{l}\text { Group V } \\
\text { (MD) }\end{array}$ & $\begin{array}{l}\text { Group VI } \\
\text { (HD) }\end{array}$ & $\begin{array}{l}\text { Group VII } \\
(H D+A-I)\end{array}$ & $\begin{array}{l}\text { Group VIII } \\
\text { (HD+A-II) }\end{array}$ & $\begin{array}{l}\text { Group VII } \\
(H D+A-I)\end{array}$ & $\begin{array}{l}\text { Group VIII }^{b} \\
\text { (HD+A-II) }\end{array}$ \\
\hline 1. & Protein levels & 12.40 & 18.18 & 59.67 & 11.41 & 10.23 & 119.70* & $122.63^{*}$ \\
\hline 2. & Lipid peroxidation & $48.31^{*}$ & $69.07^{*}$ & $278.50^{*}$ & 18.71 & 14.85 & 68.64 & 69.66 \\
\hline
\end{tabular}

All values are expressed in percentage of decrease or *increase. ${ }^{a}$ As compared to control group, ${ }^{\text {b } A s ~ c o m p a r e d ~ t o ~ t o x i n ~(h i g h-d o s e ~ l e a d ~ a c e t a t e) ~ e x p o s e d ~ G r o u p ~-~ V I, ~}$ $\mathrm{LD}=100 \mu \mathrm{M}$ lead acetate; $\mathrm{MD}=250 \mu \mathrm{M}$ lead acetate; $\mathrm{HD}=500 \mu \mathrm{M}$ lead acetate; $(\mathrm{A}-\mathrm{I})=(\mathrm{NAC}-8 \mu \mathrm{g} / \mathrm{ml}+$ ascorbic acid $-1.78 \mathrm{mg} / \mathrm{ml}+$ tocopheryl acetate $-1.42 \mathrm{mg} / \mathrm{ml}+$ thiamine $-0.3 \mathrm{mg} / \mathrm{ml})$. (A-II) =Bacopa monnieri extract $-0.1 \mathrm{mg} / \mathrm{ml}$ 
damage, which might, in turn, result in protein depletion. Thus, it is evident that the reduction in protein levels due to lead acetate exposure might subsequently lead to alteration in the structural and functional integrity of tissues. Hence, one of the principal reasons for lead-induced neurotoxicity and hepatotoxicity in the current study might be the lack of availability of proteins necessary for growth and differentiation of tissues and functioning of enzymatic systems. Our findings related to lead-induced reduction in protein levels also corroborate with the results of several scientific researchers [30-34].

The present in vitro study also revealed that lead acetate exposure caused statistically extremely significant increase in the end product of lipid peroxidation in the form of MDA in mice brain and liver homogenate cultures as compared to their respective controls. Lipid peroxidation is characterized by a deleterious process solely carried out by free radicals and manifestation of cellular deteriorative change resulting in oxidative stress generated physiological and biochemical alterations in the biological system [35].

One of the major reasons for lead-induced toxicity to mammalian tissues might be attributed to its ability to generate reactive oxygen species (ROS) leading to enhancement of complex mechanism of lipid peroxidation as the outcome of peroxidative chain events [36]. The underlying mechanism of lead toxicity involves stimulation of oxidative stress through enhancement of peroxidation of membrane lipids $[37,38]$. Enhanced oxidative stress is also evidenced by the accumulation of MDA such as by-products generated during the interaction of pro-oxidants and membrane lipids [39]. Most significant consequence of peroxidation of membrane lipids includes inactivation of cellular constituents by oxidation or induction of oxidative damage through free radical chain reaction mediated loss of membrane integrity [40] and alteration in fatty acid composition [3] leading to increase in cell membrane permeability [41] and influx of $\mathrm{Ca}^{+2}$ causing further mitochondrial damage [42]. Lead exposure is known to directly interrupt activation of enzymes, inhibit trace mineral absorption competitively, prevent protein synthesis through binding of the sulfhydryl groups, and alter calcium homeostasis [43]. Activation of free radical-mediated deleterious processes and impairment of the antioxidant defense system are recognized as the principal mechanisms involved in the pathophysiology associated with lead intoxication [44]. Lead toxicity tends to decrease the level of reduced glutathione and activities of antioxidant enzymes due to its high affinity for -SH group or metal cofactor in these enzymes which further contributes to rise in free radicals ultimately leading to enhanced lipid peroxidation $[32,45,46]$. Many researchers have reported the role of oxidative stress in leadinduced toxicity in support of our data [47-49].

Brain is believed to be the most vulnerable organ to encounter leadinduced oxidative stress leading to neurotoxicity as it has the capacity to generate a high rate of oxygen free radicals without commensurate levels of antioxidant defenses [50]. It was reported that lead increased the level of brain TBARS leading to lipid peroxidation [51] and altered the antioxidant defense system [6]. Sandhir and Gill (1995) have reported similar effects in the hepatic tissues also [21]. Generation of highly ROS and lipid peroxides aftermath lead-exposure might result in systemic mobilization and depletion of cells intrinsic antioxidant defense rendering the tissue more susceptible to free radical injury. In vitro participation of ROS and oxidative stress in plumbism appears to be supported by our observations of amplified lipid peroxidation in mice brain and liver homogenates and provides further evidence to dysregulation of pro-oxidant/antioxidant balance aftermath lead exposure. Many in vitro and in vivo studies have also reported marked enhancement in MDA levels in the lead-exposed liver, brain, and red blood cells which support our findings [10,38,43,52-55]. Rise in lipid peroxidation due to lead exposure had also been demonstrated in heart, kidney, and other organs [56,57]. Several recent studies had also confirmed the possible involvement of an increased amount of ROS in lead-exposed animals for elevated MDA levels due to direct peroxidative activity $[10,58-60]$.
In the current study, coadministration of lead and synthetic or herbal antioxidants to brain and liver homogenates in vitro significantly prevented elevation in MDA levels due to lipid peroxidation. Increase in TBARS due to lead administration was found to be reduced after vitamin supplementation with Vitamin C and Vitamin E [61]. Pande et al. (2001) also demonstrated a reduction in MDA levels by supplementation of antioxidants [62]. B. monnieri has been reported to possess antiperoxidative properties [63]. All these evidences corroborate with our findings.

In the present study, coadministration of synthetic antioxidants mixture or ethanolic extract of B. monnieri in high-dose lead-exposed mice brain and liver homogenates in vitro revealed statistically significant protection against reduction in protein contents. Selected synthetic and herbal antioxidants might be able to prevent cell injury by maintaining sulfhydryl groups of membrane binding proteins. It may be possible that compounds such as $\mathrm{N}$-acetyl cysteine imparted some protection by providing additional - $\mathrm{SH}$ groups and maintaining glutathione level in tissues against the deleterious action of lead. Dreyfus (1985) had reported that vitamins could prevent the oxidation of -SH groups during lipid peroxidation [64]. The maintenance of protein in synthetic and herbal antioxidants exposed mice brain and liver homogenates might also be credited to their protective action against -SH group oxidation.

The results of the current study also emphasized that coadministration of synthetic antioxidants or B. monnieri extract in the lead-exposed cultures significantly ameliorated lead-induced elevation in lipid peroxidation. The ameliorative action might be attributed to free radical scavenging effect and inhibition of chain reaction by synthetic antioxidants mixture and B. monnieri ethanolic extract as well as degradation of reactive aldehyde generating lipid hydroperoxides, thereby protecting the integrity of plasma membrane.

Neuroprotective, hepatoprotective as well as membrane stabilizing properties of selected synthetic antioxidants mixture and herbal antioxidant B. monnieri might be attributed to their free radicals scavenging ability, metal chelating property, ability to reduce cell protein necrosis and potential to reduce glutathione depletion. Prevention in the reduction of protein content in the lead-exposed homogenates by selected antidotes might be the result of the restoration of the energy status of the selected tissues.

Mechanism of action of synthetic antioxidants is seemed to be mainly by virtue of detoxification due to their capacity to act as powerful reducing agents and the ability to scavenge ROS. N-acetyl cysteine exhibited antioxidant capacity against lead toxicity through maintaining intracellular glutathione levels and scavenging free radicals [48]. Ascorbic acid is well known to terminate propagation of peroxidation process by acting as chain-breaking antioxidant [65]. Ascorbic acid has also been reported to restore and recycle antioxidative properties of Vitamin $\mathrm{E}$ and glutathione, when attacked by pro-oxidants $[10,66]$. Vitamin E is believed to be nature's key lipid-soluble antioxidant with peroxidation chain-breaking ability, and tocopheryl acetate is the most bioactive form of it. Vitamin $\mathrm{E}$ is well known to exert a protective effect against oxidative stress to biological membranes and lipoproteins [67]. The proposed mechanism of thiamine in alleviating lead toxicity might be attributed to its capacity to form a complex with lead metal leading to its excretion. Anna and Wiglo (2006) also had reported that thiamine could act as a potent antioxidant due to its capability to scavenge free radicals [68]. Hence, it can be interpreted that the correct combination of selected synthetic antioxidants in a mixture has the capacity to counteract lead-induced toxicity in mammals.

Medicinal herb B. monnieri possesses remarkable antioxidant properties as denoted by its ability to scavenge superoxide ions, peroxides, and hydroxyl radicals $[69,70]$. It has also been found to involve in the modulation of expression of enzymes associated with ROS scavenging activities [71]. Principle mode of action of B. monnieri includes chelation of metal ions, breaking of oxidative chain reaction [72], and improvement in activities of antioxidative defense enzymes [73]. Phytochemical 
screening of B. monnieri extract has revealed the presence of numerous pharmacologically active constituents comprising phenolics, flavonoids, alkaloids, saponins, and steroids [74,75]. These phytochemicals can act as powerful reducing agents, hydrogen donors, and singlet oxygen quenchers thereby imparting antioxidant property to the plant extract. Neuroprotective ability, hepatoprotective activity, and antioxidant potential of $B$. monnieri ethanolic extract might be attributed to the occurrence of its characteristic dammarane-type pharmacologically active constituent triterpenoid saponin termed as "Bacopside-A" [76].

Thus, synthetic antioxidants and B. monnieri exerted protection against lead toxicity-induced metabolic dysfunctions by virtue of their oxidative stress reducing potential through prevention of enhancement in lipid peroxidation and subsequent maintenance of protein levels in mice brain and liver homogenate cultures.

\section{CONCLUSION}

Outcomes of the present toxicological study clearly emphasized that lead-exposure adversely exaggerated biochemical indices of mammalian brain and liver through alterations in protein content and lipid peroxidation in vitro and ascertained that lead metal has definitely destructive effect on the metabolic and functional status of mammalian vital organs through induction of neurotoxicity and hepatotoxicity. The underlying mechanism of action for lead toxicity-induced metabolic dysfunctions encompassed excessive generation of ROS, and enhancement of lipid peroxidation mediated oxidative stress which might have resulted into alteration in cell membrane permeability and structural proteins through oxidization of membrane -SH groups.

Findings of the present synergistic study also revealed that co-supplementation of lead acetate and synthetic antioxidants mixture as well as lead acetate and ethanolic extract of B. monnieri in vitro significantly exerted protection against deleterious effects of lead intoxication. Neuroprotective and hepatoprotective potential of selected synthetic and herbal antidotes might be attributed to their anti-peroxidative, metal chelating, detoxifying, and antioxidant properties. Present investigation also revealed the greater ameliorative potential of the ethanolic extract of B. monnieri against lead toxicityinduced metabolic dysfunctions as compared to synthetic antioxidants mixture which could be credited to the synergistic action of plentiful pharmacologically active phytochemicals present in the extract.

Present research investigation holds a special significance in the field of pharmaceutical research as it has explored very effective antidotes in the form of novel combination of synthetic antioxidants mixture and B. monnieri as beneficiary ameliorative agents for the eradication of lead toxicity world over. The findings of the presentstudy would be of immense contribution in the arena of occupational toxicology for attaining better clinical recoveries in lead intoxication cases encompassing altered protein and lipid metabolism through designing of new, safe, and highly effective therapeutic strategies using antioxidants.

\section{AUTHORS' CONTRIBUTIONS}

The present research work was the outcome of equal contribution from both the authors. NKJ and FCS had carried out literature review and designed the experimental protocol. FCS participated in the collection of research study data through experimental work and performed statistical analysis. FCS had drafted the manuscript. The final draft of the manuscript was reviewed and edited under the guidance of NKJ. Both the authors had read and approved the final manuscript.

\section{COMPETING INTEREST}

Authors have declared that there are no conflicts of interest.

\section{REFERENCES}

1. Agency for Toxic Substances and Disease Registry. The Nature and Extent of Lead Poisoning in Children in the United States: A Report to Congress. DHHS Report No. 99-2966. Atlanta: US Department of Health and Human Services; 2001.

2. Garza A, Vega R, Soto E. Cellular mechanisms of lead neurotoxicity. Med Sci Monit 2006;12:57-65.

3. Gurer H, Ercal N. Can antioxidants be beneficial in the treatment of lead poisoning? Free Radic Biol Med 2000;29:927-45.

4. Paoliello MM, De Capitani EM. Environmental contamination and human exposure to lead in Brazil. Rev Environ Contam Toxicol 2005; 184:59-96.

5. Chaurasia SS, Gupta P, Kar A, Maiti PK. Lead induced thyroid dysfunction and lipid peroxidation in the fish Clarias batrachus with special reference to hepatic type i-5'-monodeiodinase activity. Bull Environ Contam Toxicol 1996;56:649-54.

6. Adonaylo VN, Oteiza PI. Lead intoxication: Antioxidant defenses and oxidative damage in rat brain. Toxicology 1999;135:77-85.

7. Abu-taweel G. Curcumin attenuates lead acetate induced neurobehavioral and neurobiochemical dysfunction: A review. Int $\mathrm{J}$ Pharm Pharm Sci 2018;10:23-8.

8. Soltaninejad K, Kebriaeezadeh A, Minaiee B, Ostad SN, Hosseini R, Azizi E, et al. Biochemical and ultrastructural evidences for toxicity of lead through free radicals in rat brain. Hum Exp Toxicol 2003;22:417-23.

9. Lanphear BP, Dietrich K, Auinger P, Cox C. Cognitive deficits associated with blood lead concentrations $<10 \mathrm{microg} / \mathrm{dL}$ in US children and adolescents. Public Health Rep 2000;115:521-9.

10. Patra RC, Swarup D, Dwivedi SK. Antioxidant effects of alpha tocopherol, ascorbic acid and L-methionine on lead induced oxidative stress to the liver, kidney and brain in rats. Toxicology 2001;162:81-8.

11. Sivaprasad R, Nagaraj M, Varalakshmi P. Combined efficacies of lipoic acid and 2,3-dimercaptosuccinic acid against lead-induced lipid peroxidation in rat liver. J Nutr Biochem 2004;15:18-23.

12. Ronis MJ, Badger TM, Shema SJ, Roberson PK, Templer L, Ringer D, et al. Endocrine mechanisms underlying the growth effects of developmental lead exposure in the rat. J Toxicol Environ Health A 1998;54:101-20.

13. Canfield RL, Henderson CR Jr., Cory-Slechta DA, Cox C, Jusko TA, Lanphear BP, et al. Intellectual impairment in children with blood lead concentrations below 10 microg per deciliter. N Engl J Med 2003;348:1517-26

14. Koller K, Brown T, Spurgeon A, Levy L. Recent developments in lowlevel lead exposure and intellectual impairment in children. Environ Health Perspect 2004;112:987-94.

15. Mudipalli A. Lead hepatotoxicity and potential health effects. Indian J Med Res 2007;126:518-27.

16. Zmudzki J, Bratton GR, Womac C, Rowe L. Lead poisoning in cattle: Reassessment of minimum toxic oral dose. Bull Environ Contam Toxicol 1983;30:435-41.

17. Aziz FM, Maulood IM, Chawsheen MA. Effects of melatonin, Vitamin C and Vitamin E alone or in combination on lead-induced injury in liver and kidney organs of rats. IOSR J Pharm 2012;2:13-8.

18. Prabha P, Rajkumar J. Histological study on protective effect of aquatic weed Hydrilla verticillata against lead induced toxicity in fish. Int $\mathrm{J}$ Pharm Pharm Sci 2015;8:132-6.

19. Lowry OH, Rosebrough NJ, Farr AL, Randall RJ. Protein measurement with the folin phenol reagent. J Biol Chem 1951;193:265-75.

20. Ohkawa H, Ohishi N, Yagi K. Assay for lipid peroxides in animal tissues by thiobarbituric acid reaction. Anal Biochem 1979;95:351-8.

21. Sandhir R, Gill KD. Effect of lead on lipid peroxidation in liver of rats. Biol Trace Elem Res 1995;48:91-7.

22. Chiba M, Shinohara A, Matsushita K, Watanabe H, Inaba Y. Indices of lead-exposure in blood and urine of lead-exposed workers and concentrations of major and trace elements and activities of SOD, GSHpx and catalase in their blood. Tohoku J Exp Med 1996;178:49-62.

23. Halliwell B, Gutteridge JM. The definition and measurement of antioxidants in biological systems. Free Radic Biol Med 1995;18:125-6.

24. Esterbauer H. Lipid peroxidation products formation, Chemical properties and biological activities. In: Poli G, Cheesman $\mathrm{KH}$, Dianzani MV, Slater TF. Free Radical in Liver Injury. Oxford, IRL Press Ltd.; 1986. p. 29-45.

25. Vallee BL, Ulmer DD. Biochemical effects of mercury, cadmium, and lead. Annu Rev Biochem 1972;41:91-128.

26. Shashi A, Thapar SP, Singh JP. Effects of fluoride administration on organs of gastrointestinal tract-an experimental study on rabbits-effects on tissue proteins. Fluoride 1987;20:183-8.

27. Shalan MG, Mostafa MS, Hassouna MM, El-Nabi SE, El-Refaie A. Amelioration of lead toxicity on rat liver with Vitamin C and silymarin supplements. Toxicology 2005;206:1-5.

28. Sajitha GR, Jose R, Andrews A, Ajantha KG, Augustine P, Augusti KT, 
et al. Garlic oil and Vitamin E prevent the adverse effects of lead acetate and ethanol separately as well as in combination in the drinking water of rats. Indian J Clin Biochem 2010;25:280-8.

29. Simons TJ. Lead-calcium interactions in cellular lead toxicity. Neurotoxicology 1993;14:77-85.

30. Needleman HL, Bellinger D. The health effects of low level exposure to lead. Annu Rev Public Health 1991;12:111-40.

31. El-Zayat EM, El-Ymany NA, Kamel ZH. Combined supplementation of zinc and vitamin $\mathrm{C}$ as protective agents against lead toxicity in growing male albino rats. Liver functions. J Egypt Ger Soc Zool 1996;20: 115-39.

32. Sharma A, Sharma V, Kansal L. Amelioration of lead-induced hepatotoxicity by Allium sativum extracts in Swiss albino mice. Libyan J Med 2010;5:4621.

33. Sharma V, Sharma A, Kansal L. The effect of oral administration of Allium sativum extracts on lead nitrate induced toxicity in male mice. Food Chem Toxicol 2010;48:928-36.

34. Sharma S, Sharma V, Sharma SP. Therapeutic potential of hydromethanolic root extract of Withania somnifera on neurological parameters in Swiss albino mice subjected to lead nitrate. Int J Curr Pharm Res 2011;3:52-6.

35. Patrick L. Lead toxicity part II: The role of free radical damage and the use of antioxidants in the pathology and treatment of lead toxicity. Altern Med Rev 2006;11:114-27.

36. Halliwell B. Mechanisms involved in the generation of free radicals. Pathol Biol (Paris) 1996;44:6-13.

37. Kang JK, Sul D, Kang JK, Nam SY, Kim HJ, Lee E, et al. Effects of lead exposure on the expression of phospholipid hydroperoxidase glutathione peroxidase mRNA in the rat brain. Toxicol Sci 2004;82:228-36

38. Caylak E, Aytekin M, Halifeoglu I. Antioxidant effects of methionine, alpha-lipoic acid, $\mathrm{N}$-acetylcysteine and homocysteine on lead-induced oxidative stress to erythrocytes in rats. Exp Toxicol Pathol 2008;60: 289-94.

39. Janero DR. Malondialdehyde and thiobarbituric acid-reactivity as diagnostic indices of lipid peroxidation and peroxidative tissue injury. Free Radic Biol Med 1990;9:515-40.

40. Maiti PK, Kar A, Gupta P, Chaurasia SS. Loss of membrane integrity and inhibition of type-I iodothyronine 5'-monodeiodinase activity by fenvalerate in female mouse. Biochem Biophys Res Commun 1995; 214:905-9

41. Subramaniam S, Shyama S, Shyamaladevi CS. Protective effect of Vitamin E against CMF-induced damages in small intestinal brush border membrane of rats. Indian J Pharmacol 1994;26:213-7.

42. Marks DB, Marks AD, Smith CM. Basic medical biochemistry-A clinical approach. Enzyme, Chapter: 9, p. 99-128, Oxygen metabolism and oxygen Toxicity. Ch.21, p. 327-339 and Cholesterol metabolism and the blood lipoproteins, Chapter: 34, p. 525-544. Williams and Wilkins, A Wavery Company, Baltimore, Maryland, USA; 1996.

43. Ercal N, Gurer-Orhan H, Aykin-Burns N. Toxic metals and oxidative stress part I: Mechanisms involved in metal-induced oxidative damage. Curr Top Med Chem 2001;1:529-39.

44. El-Sokkary GH, Abdel-Rahman GH, Kamel ES. Melatonin protects against lead-induced hepatic and renal toxicity in male rats. Toxicology 2005;213:25-33

45. Upsani CD, Bataraman R. Effect of Vitamin E, Vitamin C and spirulina on the levels of membrane bound enzymes and lipids in some organs of rats exposed to lead. Indian J Pharmacol 2003;33:185-91.

46. Mohammad IK, Mahdi AA, Raviraja A, Najmul I, Iqbal A, Thuppil V, et al. Oxidative stress in painters exposed to low lead levels. Arh Hig Rada Toksikol 2008;59:161-9.

47. Sandhir R, Julka D, Gill KD. Lipoperoxidative damage on lead exposure in rat brain and its implications on membrane bound enzymes. Pharmacol Toxicol 1994; 74:66-71

48. Ercal N, Treeratphan P, Lutz P, Hammond TC, Matthews RH. $\mathrm{N}$-actylcysteine protects Chinese hamster ovary (CHO) cells from leadinduced oxidative stress. Toxicology 1996;108:57-64.

49. Gürer H, Ozgünes H, Neal R, Spitz DR, Erçal N. Antioxidant effects of $\mathrm{N}$-acetylcysteine and succimer in red blood cells from lead-exposed rats. Toxicology 1998;128:181-9.

50. Villeda-Hernández J, Barroso-Moguel R, Méndez-Armenta M, NavaRuíz C, Huerta-Romero R, Ríos C, et al. Enhanced brain regional lipid peroxidation in developing rats exposed to low level lead acetate. Brain Res Bull 2001;55:247-51.

51. Upasani CD, Khera A, Balaraman R. Effect of lead with Vitamin E, C, or spirulina on malondialdehyde, conjugated dienes and hydroperoxides in rats. Indian J Exp Biol 2001;39:70-4.
52. Shukla PK, Khanna VK, Khan MY, Srimal RC. Protective effect of curcumin against lead neurotoxicity in rat. Hum Exp Toxicol 2003; 22:653-8.

53. Daniel S, Limson JL, Dairam A, Watkins GM, Daya S. Through metal binding, curcumin protects against lead- and cadmium-induced lipid peroxidation in rat brain homogenates and against lead-induced tissue damage in rat brain. J Inorg Biochem 2004;98:266-75.

54. Bennet C, Bettaiya R, Rajanna S, Baker L, Yallapragada PR, Brice JJ, et al. Region specific increase in the antioxidant enzymes and lipid peroxidation products in the brain of rats exposed to lead. Free Radic Res 2007;41:267-73.

55. Kansal L, Sharma V, Sharma A, Lodi S, Sharma SH. Protective role of Coriandrum sativum (coriander) extracts against lead nitrate induced oxidative stress and tissue damage in the liver and kidney in male mice. Int J Appl Biol Pharm 2011;2:65-83.

56. Gurer H, Ozgunes H, Oztezcan S, Ercal N. Antioxidant role of alphalipoic acid in lead toxicity. Free Radic Biol Med 1999;27:75-81.

57. Patra RC, Rautray AK, Swarup D. Oxidative stress in lead and cadmium toxicity and its amelioration. Vet Med Int 2011;2011:457327.

58. Pande M, Flora SJ. Lead induced oxidative damage and its response to combined administration of alpha-lipoic acid and succimers in rats. Toxicology 2002;177:187-96.

59. Aykin-Burns N, Laegeler A, Kellogg G, Ercal N. Oxidative effects of lead in young and adult fisher 344 rats. Arch Environ Contam Toxicol 2003;44:417-20

60. Caylak E, Halifeoiglu I, Aydin S, Telo S, Bulmus O, Celik H. The effects of sulfur-containing compounds on total antioxidant capacity levels of liver, kidney and brain in lead-exposed rats. Turkiye Klinikleri J Med Sci 2007;27:823-8.

61. Flora SJ, Pande M, Mehta A. Beneficial effect of combined administration of some naturally occurring antioxidants (vitamins) and thiol chelators in the treatment of chronic lead intoxication. Chem Biol Interact 2003;145:267-80.

62. Pande M, Mehta A, Pant BP, Flora SJ. Combined administration of a chelating agent and an antioxidant in the prevention and treatment of acute lead intoxication in rats. Environ Toxicol Pharmacol 2001;9: 173-84.

63. Kapoor R, Srivastava S, Kakkar P. Bacopa monnieri modulates antioxidant responses in brain and kidney of diabetic rats. Environ Toxicol Pharmacol 2009;27:62-9.

64. Dreyfus PM. The neurochemistry of vitamin deficiencies. In: Lajtha A, editor. Handbook of Neurochemistry. Vol. 10. New York: Plenum Press; 1985. p. 757-77

65. Chan AC. Partners in defense, Vitamin E and Vitamin C. Can J Physiol Pharmacol 1993;71:725-31.

66. Leung HW, Vang MJ, Mavis RD. The cooperative interaction between Vitamin E and Vitamin C in suppression of peroxidation of membrane phospholipids. Biochim Biophys Acta 1981;664:266-72.

67. Chaurasia S, Kar A. Protective effects of Vitamin E against lead induced destruction of membrane associated Type-I iodothyronine 5'-monodeiodinase (5'DI) activity in male mice. Toxicology 1997; 124:203-9.

68. Anna G, Wiglo S. Antioxidant activity of water soluble vitamins in TEAC (trolox equivalent antioxidant capacity) and the FRAP (Ferric Reducing Antioxidant Power) assays. Food Chem 2006;96:131-6.

69. Cook NC, Samman S. Flavanoids-chemistry, metabolism, cardio protective effects and dietary sources. J Nutr Biochem 1996;7:66-76.

70. Srivastava S, Mishra N, Misra U. Bacopa monnieri a future perspective. Int J Pharm Sci Drug Res 2009;1:154-7.

71. Pawar R, Gopalakrishnan C, Bhutani KK. Dammarane triterpene saponin from Bacopa monniera as the superoxide inhibitor in polymorphonuclear cells. Planta Med 2001;67:752-4.

72. Tripathi YB, Chaurasia S, Tripathi E, Upadhyay A, Dubey GP. Bacopa monniera Linn. As an antioxidant: Mechanism of action. Indian J Exp Biol 1996;34:523-6.

73. Bhattacharya SK, Kumar A, Ghosal S. Effect of Bacopa monniera on animal models of Alzheimer disease and perturbed central cholinergic markers of congnition in rats. In: Sankar DV, editor. Molecular Aspects of Asian Medicines. New York: PJD Publications; 2000.

74. Jyoti A, Sharma D. Neuroprotective role of Bacopa monniera extract against aluminium-induced oxidative stress in the hippocampus of rat brain. Neurotoxicology 2006;27:451-7.

75. Rameshwari R, Abirami H, Catharin S. Pharmacological actions of Bacopa monnieri: A review. Int J Pharm Ind Res 2013;3:158-67.

76. Sumathi T, Nongbri A. Hepatoprotective effect of bacoside-A, a major constituent of Bacopa monniera Linn. Phytomedicine 2008;15:901-5. 